\title{
Pseudotachylytes from Corsica: fossil earthquakes from a subduction complex
}

\author{
Håkon Austrheim and Torgeir B. Andersen \\ Department of Geosciences - PGP, University of Oslo, PO Box 1047 Blindern, 0316 Oslo, Norway
}

\begin{abstract}
Subduction zones are the most seismically active tectonic environment on Earth. Here we report fault-rock evidence of palaeoearthquakes from a subduction complex. Pseudotachylyte veins formed by shear heating on faults at seismic strain rates contain dendrites, spherulites and acicular minerals characteristic of blueschist facies conditions. The veins have
\end{abstract}

\begin{abstract}
been found in both mantle peridotite and gabbro. Our discovery from Corsica opens a new avenue of research towards understanding mechanisms related to subduction zone earthquakes and the conditions at which these are released.
\end{abstract}

Terra Nova, 16, 193-197, 2004

\section{Introduction}

Tectonic processes along convergent plate margins, particularly in subduction zones, generate most of the global energy radiated by earthquakes. Although the mechanism behind interplate earthquakes is generally related to stick-slip during underthrusting on shallowly dipping fault planes, there are a number of phenomena regarding intra- and interplate earthquakes that await explanation. A major unresolved question concerns the interaction of earthquakes with fluids and metamorphic processes (Hacker et al., 2003; Lund and Austrheim, 2003). Subduction zones are typified by low geothermal gradients, where high differential stresses may result in fracturing rather than creep. Although most models view the properties of subducted crust as a function of temperature, it is increasingly recognized that the rheological properties of rocks depend on their metamorphic status and importantly on the fluid content. Release of fluids from dehydration reactions in subduction complexes will reduce the effective stress and allow brittle failure (Hacker et al., 2003), but fluids may also reduce the likelihood for frictional melting in shear zones (Sibson, 1975). Blueschist terrains are characterized by low-temperature and high-pressure (LT-HP) metamorphism and are often regarded

Correspondence: Håkon Austrheim, Department of Geology - PGP, University of Oslo, PO Box 1047 Blindern, 0316 Oslo, Norway. Tel.: + 47 22854316; e-mail: hakon. austrheim@geo.uio.no as having formed in the upper 15$50 \mathrm{~km}$ of subduction zones. Such rock complexes are potential sources for direct observational information regarding the physical properties of subducted rocks.

\section{Geological setting}

The Alpine HP-LT complex of Corsica (Fig. 1) contains carpholite schists, blueschist and eclogite facies rocks formed by late Cretaceous (?) early Tertiary subduction, involving thrust stacking and accretion of European continental crust and Ligurian oceanic units on to the margin of Europe (cf. Figure 4 in Jolivet et al., 2003). The HP-LT rocks include a dismembered ophiolite dominated by variably metamorphosed ultramafics, gabbros, pillow lavas and metasedimentary schists (the Schistes Lustrés units), as well as allochthonous blueschist (Sera di Pigno Unit) and eclogite facies (Monte Pinatelle - Farinole Unit) rocks developed from the Hercynian basement (Warburton, 1986; Fournier et al., 1991). The eclogites of the Cap Corse Region record peak Alpine metamorphic conditions of $P \approx 15-20 \mathrm{kbar}$ and $T \approx 550 \pm 50^{\circ} \mathrm{C}$. They were exhumed on a cold geotherm through the blueschist facies at $P \approx 7-9 \mathrm{kbar}$ and $T \approx 450-500{ }^{\circ} \mathrm{C}$ and eventually to greenschist facies (Fournier et al., 1991; Lahondre, 1988). Other units without eclogites reached $P_{\max }$ at lawsonite-blueschist facies $(P \approx 13$ $15 \mathrm{kbar}$ at $T \approx 350-400^{\circ} \mathrm{C}$ ) and decompressed on a cold geotherm through blueschist $(P \approx 10 \mathrm{kbar}$, $T \approx 350{ }^{\circ} \mathrm{C}$ ) to greenschist facies conditions (Fournier et al., 1991).

\section{The fault rocks}

Pseudotachylyte veins occur in gabbros and mantle peridotites exposed around the peak of Cima di Gratera (Fig. 1). The Cima di Gratera gabbro is a cumulate-layered to varied-textured gabbro. The gabbro is partly transformed to blueschist facies, except in shear zones (Fournier et al., 1991) where the transformation has run to completion. Our field observations suggest that parts of the gabbros that were incorporated into the subduction complex remained undeformed and partly unreacted during both subduction and the subsequent exhumation, and that the pseudotachylytes are located in the least reacted parts. The pseudotachylytes can also be studied in boulders on the beach at Sole du Marine (Fig. 1) and along the river Fium Albino, draining the Cima de Gratera area (dotted line in Fig. 1). A large number of gabbro and some peridotite boulders with partly preserved primary structures, textures and mineralogy display fine-grained, brittle-deformation zones and pseudotachylyte zones (Figs 2 and 3).

The pseudotachylytes are dark, grey, occasionally greenish to bluish, aphanitic veins, $<3 \mathrm{~cm}$ thick. They are clearly related to faults and form single discrete veins, injection-vein complexes and ladder-network breccias (Fig. 2a,b). Several examples of cross-cutting veins of different generations (Fig. 2a) indicate a polyphase slip history on the faults. Locally, small pull-apart mesoscopic structures have been opened and filled with pseudotachylyte (Fig. 2a). Some samples preserve evidence of interaction between brittle and ductile deforma- 


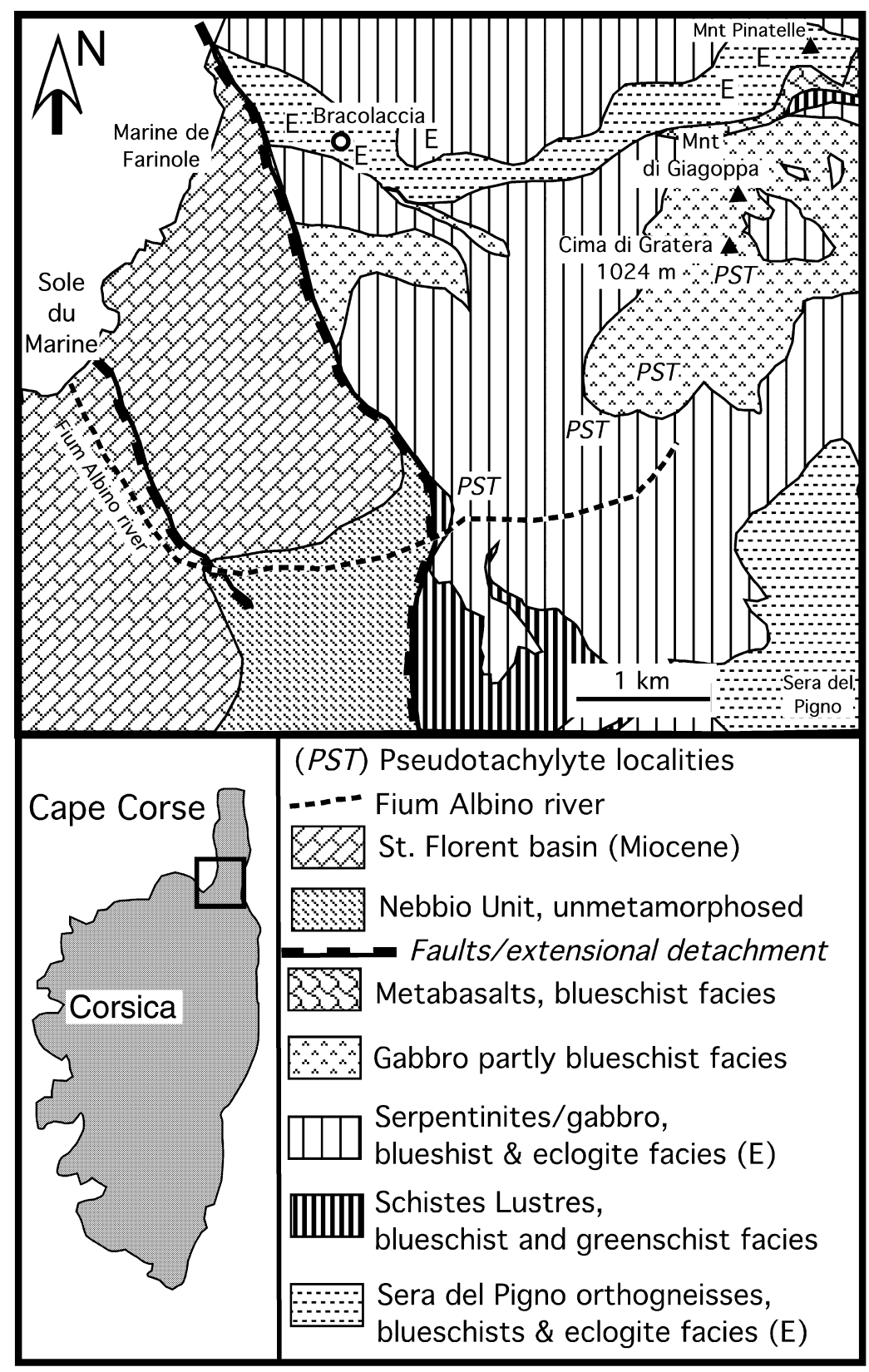

Fig. 1 Simplified geological map of the St. Florent area with an inset map of Corsica. Modified from Fournier et al. (1991).

tion as shear strain gradients locally can be observed along fault-vein margins, and some veins are partly overprinted by ductile fabrics (Fig. 2b). A colour banding defined by variable size and/or content of porphyroclasts and commonly convoluted by folds is present in many veins. Textural and mineralogical characteristics of the veins and their wall-rocks are given in Table 1. The gabbro-hosted veins locally display intricate dendrites
(Figs 2c and 3b,c) of fassaitic pyroxene (Table 2). Veins $0.2-1 \mathrm{~cm}$ across have a central part with $10 \mu \mathrm{m}$ euhedral pyroxene crystals, some of which have cores of diopside (Fig. 3c). The vein margins are characterized by dendrites and spherulites (Fig. 3c,d). The dendrites branch outward from orthopyroxene clasts that are partly replaced by talc (Fig. 3d). The hydration of orthopyroxene to talc cannot have occurred after the growth of the
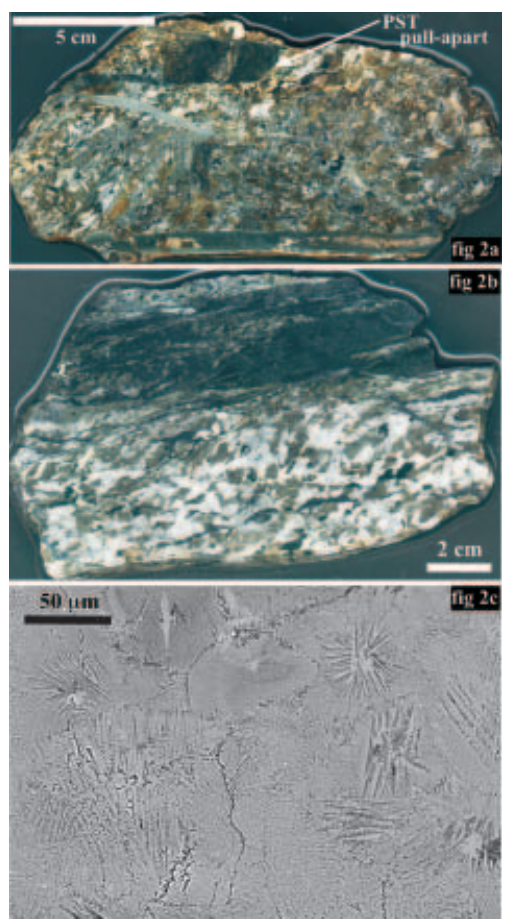

Fig. 2 (a) Multiple-generation faultbreccia of gabbro with network of pseudotachylyte veins. Notice pull-apart with fragments of wall-rock (top and bottom) filled with pseudotachylyte. (b) Pseudotachylyte vein along right-lateral fault, showing a shear-strain gradient defined by the foliation in the gabbro wall-rock highlighted by dotted white lines in the figure. (c) BSE image (Cor30) of spherulitic texture in pseudotachylyte, with epidote, dendritic fassaite and plagioclase.

dendrite as this would have destroyed the delicate texture. Acicular epidote grains locally form spherulites. The clasts and wall-rock minerals are similar in composition, suggesting that they are locally derived. The fassaitic pyroxene contains up to $18 \mathrm{wt} \%$ $\mathrm{Al}_{2} \mathrm{O}_{3}$ as jadeite, Ca-tschermak and in the most Al-rich pyroxenes up to 15 mol.\% Ca-Eskola component. Fassaitic pyroxenes with similar composition have been reported from pseudotachylytes in the Musgrave range, Central Australia (Wenk and Weiss, 1982). Wenk and Weiss (1982) pointed out that the high Al-pyroxene was similar to pyroxenes from eclogites and kimberlites that formed at $30 \mathrm{kbar}$ and argued that the high pressure represented dynamic stresses released during catastrophic brittle failure. Fassaitic pyroxenes have also 


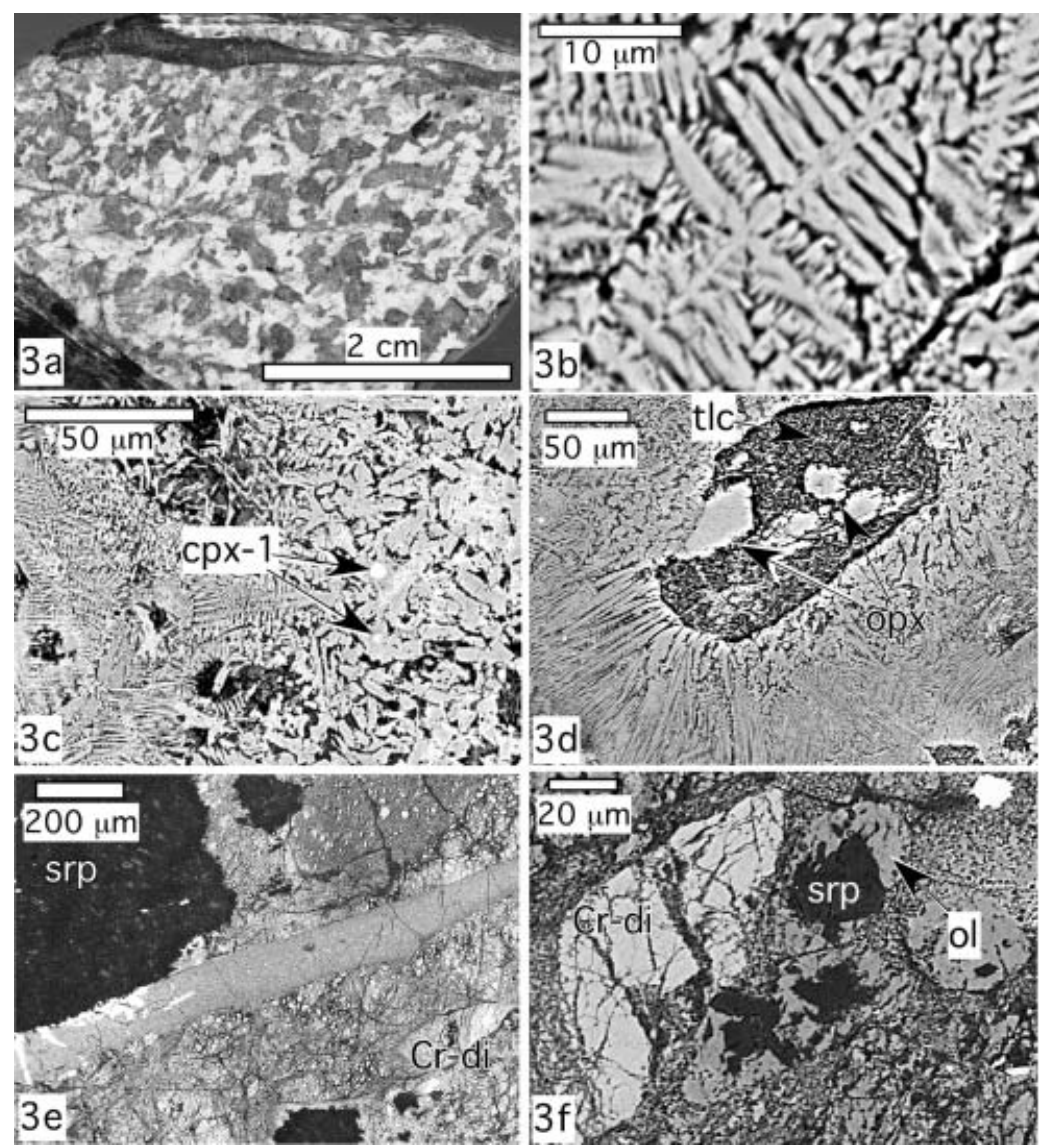

Fig. 3 (a) Pseudotachylyte vein containing fassaitic cpx, boulder (sample Cor30) from the beach at Sole du Marine (all mineral abbreviations after Kretz, 1983). (b) Backscattered electron (BSE) image from pseudotachylyte, showing dendrite of fassaitic cpx. (c) BSE image showing centre (right) to rim (left) of pseudotachylyte vein (Cor30). The centre contains euhedral crystals of fassaitic cpx locally surrounding clasts of cpx (cpx-1). The rim of the vein is characterized by dendrites of fassaitic cpx. (d) BSE image from pseudotachylyte vein (Cor30), showing dendrite of fassaitic cpx that has grown out from clasts consisting of relict opx partly replaced by talc. Talc must have formed before the faulting. (e) BSE image of pseudotachylyte vein transecting peridotite. Note that serpentinization stops at the margin of the vein. (f) BSE image of pseudotachylyte vein showing serpentine with overgrowth of younger olivine. Note also clast of Cr-diopside. been produced during frictional melting experiments at $10 \mathrm{kbar}$ conducted to simulate earthquakes at amphibolite facies conditions (Spray, 1988). Some of the gabbro-hosted veins contain blueschist facies parageneses including 10-20 $\mu \mathrm{m}$ sodic amphibole grains that are typically zoned from edenitic cores to glaucophane rims (Table 2) or from actinolite to edenite. Pumpellyite, albite, epidote and titanite typically coexist with amphibole (Table 2).

The peridotite contains remnants of primary olivine $\left(\mathrm{Fo}_{91}\right)$, chromediopside $\left(\mathrm{Wo}_{46} \mathrm{En}_{51} \mathrm{Fs}_{4}\right)$, orthopyroxene $\left(\mathrm{En}_{88}\right)$ and a Cr-rich spinel. Such minerals are typical for spinel lherzolites of mantle origin. Ultrafinegrained, millimetre- to centimetrethick injection and fault veins of pseudotachylyte containing clasts of Cr-diopside and olivine transect the peridotite (Fig. 3e). Olivine close to the vein is granulated and locally contains injection veins. A characteristic and intriguing feature observed in pseudotachylyte-like veins are serpentine inclusions partly surrounded by neoblastic olivine (Fo90) (Fig. 3f). The interpretation of these textures is not clear, but the dehydration reaction serpentine $=$ olivine $+\mathrm{H}_{2} \mathrm{O}$ may have occurred. The replacement of serpentine by olivine requires a minimum temperature of $c .450{ }^{\circ} \mathrm{C}$ at a pressure of $10 \mathrm{kbar}$ (Bucher and Frey, 1994). Because the dehydration textures have not been observed outside the vein it is suggested that the dehydration occurred as a response to shear heating and not to a regional temperature increase. The serpentine

Table 1 Petrography of pseudotachylyte veins and their wall rocks

\begin{tabular}{|c|c|c|c|c|c|c|c|}
\hline \multirow[b]{2}{*}{ Sample } & \multicolumn{3}{|l|}{ Vein } & \multicolumn{4}{|l|}{ Wallrock } \\
\hline & Clast & Neolith & Texture & Primary minerals & Secondary minerals & Textures & Rock type \\
\hline Cor29a & di, ol, srp & ol & ol growth on srp clasts & ol, cpx, opx, spl & srp, chl, mt & $\mathrm{chl}$ rims on $\mathrm{mt}$ & peridotite \\
\hline Cor30 & $\begin{array}{r}\text { di, pl, srp, } \\
\text { tc }+ \text { opx }\end{array}$ & fst, zo, pl, tre & $\begin{array}{l}\text { dend, sphe, opx growth } \\
\text { on tlc }\end{array}$ & di, pl, hbl, ol/opx & tlc, ep, pl & ol/opx replaced by tc, plag & $\mathrm{gb}$ \\
\hline Cor32 & $\mathrm{di}, \mathrm{pl}$ & act, ep, ab, chl & & di, pl, ol/opx & tlc, ep, pl & strong alteration & $g b$ \\
\hline Cor36 & $\mathrm{pl}+\mathrm{ep}, \mathrm{chl}$ & pmp, amph, ep & zoned amph(ed-act) & $\mathrm{pl}, \mathrm{cpx} / \mathrm{ol} / \mathrm{opx}$ & $\begin{array}{l}\text { chl, epid, } \\
\text { alb, amph }\end{array}$ & strong hydration & $g b$ \\
\hline Cor48c & ep & gln, Pmp, pl, spn & zoned amph(gln-act) & cpx, pl & ep, $a b$ & plag altered to alb + ep & $\mathrm{gb}$ \\
\hline Cor47 & $\mathrm{di}$ & amph & & cpx, pl & & $\begin{array}{l}\mathrm{kb} \text { and } \mathrm{db} \text { in } \mathrm{cpx}, \mathrm{pl} \\
\text { altered to zo }+ \text { alb }\end{array}$ & $g b$ \\
\hline Cor62 & di, aug, pl & fst, pl, amph & fst growth on di clasts & $\mathrm{cpx}, \mathrm{pl}$ & ep, ab & $\mathrm{kb}$ and $\mathrm{db}$ in $\mathrm{cpx}$ & $\mathrm{gb} / \mathrm{do}$ \\
\hline
\end{tabular}

Mineral abbreviations after Kretz (1983).

Additional abbreviations: gabbro, gb; dolerite, do; dendrite, dend; spherulite, sphe; kink bands, Kb; deformation bands, db. 
Table 2 Compositions of pyroxenes and amphiboles from pseudotachylyte veins and their wallrock

\begin{tabular}{|c|c|c|c|c|c|c|c|c|c|c|c|c|c|c|c|}
\hline $\begin{array}{l}\text { Sample } \\
\text { Texture } \\
\text { Mineral }\end{array}$ & $\begin{array}{l}\text { Cor30 } \\
\text { dend. } \\
\text { fst }\end{array}$ & $\begin{array}{l}\text { Cor30 } \\
\text { clast } \\
\text { di }\end{array}$ & $\begin{array}{l}\text { Cor30 } \\
\text { dend. } \\
\text { fst }\end{array}$ & $\begin{array}{l}\text { Cor30 } \\
\text { neolith } \\
\text { fst }\end{array}$ & $\begin{array}{l}\text { Cor30 } \\
\text { dend. } \\
\text { fst }\end{array}$ & $\begin{array}{l}\text { Cor62 } \\
\text { neolith } \\
\text { fst }\end{array}$ & $\begin{array}{l}\text { Cor29 } \\
\text { pri. min. } \\
\text { cr-di }\end{array}$ & $\begin{array}{l}\text { Cor29 } \\
\text { pri. min. } \\
\text { opx }\end{array}$ & $\begin{array}{l}\text { Cor30 } \\
\text { clast } \\
\text { opx }\end{array}$ & & $\begin{array}{l}\text { Cor36 } \\
\text { core } \\
\text { ktp }\end{array}$ & $\begin{array}{l}\text { Cor36 } \\
\text { rim } \\
\text { tr }\end{array}$ & $\begin{array}{l}\text { Cor } 48 \mathrm{C} \\
\text { core } \\
\text { bar }\end{array}$ & $\begin{array}{l}\text { Cor48C } \\
\text { rim } \\
\text { bar }\end{array}$ & $\begin{array}{l}\text { Cor48C } \\
\text { core } \\
\text { gln }\end{array}$ \\
\hline $\mathrm{SiO}_{2}$ & 50.7 & 50.71 & 50.6 & 48.39 & 50.84 & 49.72 & 50.88 & 53.88 & 54.33 & & 45.26 & 57.81 & 44.64 & 57.37 & 57.58 \\
\hline $\mathrm{TiO}_{2}$ & 0.49 & 1.19 & 0.39 & 0.32 & 0.32 & 0.34 & 0.28 & 0.14 & 0.29 & & 1.19 & 0.04 & 0.28 & 0 & 0 \\
\hline $\mathrm{Al}_{2} \mathrm{O}_{3}$ & 16.21 & 3.7 & 12.93 & 14.05 & 18.54 & 10.94 & 5.5 & 5.89 & 1.38 & & 10.63 & 1.22 & 13.86 & 11.39 & 11.37 \\
\hline $\mathrm{FeO}$ & 5.28 & 8.03 & 5.65 & 5.17 & 4.93 & 4.92 & 2.15 & 6.67 & 13.64 & & 16.57 & 5.42 & 10.01 & 8.46 & 8.16 \\
\hline $\mathrm{MnO}$ & 0.19 & 0.14 & 0.19 & 0.14 & 0.16 & 0.11 & 0.03 & 0.14 & 0.32 & & 0.44 & 0.15 & 0.04 & 0.07 & 0.04 \\
\hline $\mathrm{MgO}$ & 11.04 & 14.24 & 15.32 & 15.99 & 9.88 & 16.86 & 17.42 & 32.35 & 28.35 & & 10.96 & 19.84 & 15.12 & 11.78 & 11.46 \\
\hline $\mathrm{CaO}$ & 13.93 & 20.77 & 13.26 & 14.63 & 13.85 & 16.48 & 21.89 & 0.71 & 1.22 & & 8.05 & 12.84 & 8.91 & 2.72 & 2.28 \\
\hline $\mathrm{Na}_{2} \mathrm{O}$ & 2.37 & 0.52 & 1.63 & 0.97 & 2.69 & 0.8 & 0.76 & 0.06 & 0.05 & & 4.2 & 0.38 & 4.02 & 6.18 & 6.41 \\
\hline $\mathrm{K}_{2} \mathrm{O}$ & 0 & 0 & 0 & 0 & 0 & 0 & 0 & 0 & 0 & & 0.03 & 0 & 0 & 0 & 0.12 \\
\hline $\mathrm{Cr}_{2} \mathrm{O}_{3}$ & 0 & 0.35 & 0.14 & 0.16 & 0.09 & 0.12 & 1.22 & 0.63 & 0.13 & & 0 & 0.04 & 0.01 & 0.01 & 0.01 \\
\hline Total & 100.21 & 99.65 & 100.11 & 99.82 & 101.3 & 100.29 & 100.13 & 100.47 & 99.71 & & 97.33 & 97.74 & 96.89 & 97.98 & 97.43 \\
\hline \multicolumn{16}{|c|}{ Structural formula based on $6(0)$ and $23(0)$ for pyroxene and amphiboles, respectively } \\
\hline $\mathrm{Si}$ & 1.799 & 1.89 & 1.804 & 1.737 & 1.779 & 1.785 & 1.852 & 1.862 & 1.953 & $\mathrm{Si}$ & 6.743 & 7.998 & 6.474 & 7.655 & 7.886 \\
\hline $\mathrm{Al}^{\mathrm{IV}}$ & 0.201 & 0.11 & 0.196 & 0.263 & 0.221 & 0.215 & 0.148 & 0.138 & 0.047 & & & & & & \\
\hline $\mathrm{Al}^{\mathrm{VI}}$ & 0.477 & 0.053 & 0.347 & 0.331 & 0.544 & 0.248 & 0.88 & 0.102 & 0.005 & $\mathrm{Al}$ & 1.866 & 0.199 & 2.369 & 1.791 & 1.835 \\
\hline $\mathrm{Ti}$ & 0.013 & 0.033 & 0.01 & 0.009 & 0.008 & 0.009 & 0.008 & 0.004 & 0.008 & $\mathrm{Ti}$ & 0.133 & 0.004 & 0.031 & 0 & 0 \\
\hline $\mathrm{Cr}^{3+}$ & 0 & 0.012 & 0.005 & 0.006 & 0.002 & 0.003 & 0.029 & 0.016 & 0.003 & $\mathrm{Cr}$ & 0 & 0.001 & 0 & 0 & 0 \\
\hline $\mathrm{Fe}$ & 0.157 & 0.25 & 0.168 & 0.155 & 0.144 & 0.148 & 0.065 & 0.193 & 0.41 & $\mathrm{Fe}$ & 2.064 & 0.627 & 1.214 & 0.944 & 0.934 \\
\hline $\mathrm{Mn}$ & 0.006 & 0.004 & 0.006 & 0.004 & 0.005 & 0.003 & 0.001 & 0.004 & 0.01 & $\mathrm{Mn}$ & 0.056 & 0.018 & 0.005 & 0.008 & 0.005 \\
\hline $\mathrm{Mg}$ & 0.584 & 0.791 & 0.814 & 0.856 & 0.515 & 0.902 & 0.945 & 1.667 & 1.519 & $\mathrm{Mg}$ & 2.434 & 4.092 & 3.269 & 2.861 & 2.34 \\
\hline $\mathrm{Ca}$ & 0.53 & 0.829 & 0.506 & 0.563 & 0.519 & 0.634 & 0.854 & 0.026 & 0.047 & $\mathrm{Ca}$ & 1.285 & 1.903 & 1.384 & 0.389 & 0.335 \\
\hline \multirow[t]{2}{*}{$\mathrm{Na}$} & 0.163 & 0.038 & 0.113 & 0.067 & 0.183 & 0.056 & 0.054 & 0.004 & 0.003 & $\mathrm{Na}$ & 1.213 & 0.102 & 1.13 & 1.599 & 1.702 \\
\hline & & & & & & & & & & K & 0.006 & 0 & 0 & 0 & 0.021 \\
\hline Sum cations & 3.93 & 4.011 & 3.97 & 3.99 & 3.921 & 4.002 & 4.044 & 4.015 & 4.011 & & 15.794 & 14.944 & 15.875 & 15.247 & 15.036 \\
\hline $\mathrm{Na}(\mathrm{Mg}, \mathrm{Ti}) 0.5 \mathrm{Si}_{2} \mathrm{O}_{6}$ & 0.03 & & 0.02 & 0.02 & 0.02 & & & & & & & & & & \\
\hline $\mathrm{Jd}$ & 0.14 & & 0.09 & 0.05 & 0.17 & & & & & & & & & & \\
\hline CaEs & 0.14 & & 0.06 & 0.02 & 0.16 & & & & & & & & & & \\
\hline CaTs & 0.2 & & 0.2 & 0.26 & 0.22 & & & & & & & & & & \\
\hline Aug & 0.06 & & 0.08 & 0.03 & 0 & & & & & & & & & & \\
\hline Opx & 0.34 & & 0.45 & 0.49 & 0.33 & & & & & & & & & & \\
\hline
\end{tabular}

End-members calculated for pyroxene with sum cations < 4 according to Katayama et al. (2000).

Cor30, 36, 48 and 62: gabbro. Cor29: peridotite. Abbreviations as in footnotes to Table 1.

indicates that some hydrous minerals were present prior to faulting.

The gabbro wall-rock is variably hydrated. Plagioclase is typically altered to epidote and albite. Clinopyroxene is locally replaced by actinolite and chlorite. Orthopyroxene is altered to aggregates of quartz, chlorite and actinolite or replaced by talc. Olivine in the peridotite is locally replaced by serpentine and magnetite, the latter often along fractures. Cr-spinel is rimmed by chlorite. Although some hydration must have taken place prior to faulting, as demonstrated by clasts of serpentine and talc, the hydration also continued after faulting as veins in the peridotite are replaced by serpentine and magnetite along fractures and locally are totally overprinted by serpentine.

The contacts with wall-rocks in both gabbro- and peridotite-hosted veins are sharp, and the wall-rock is transected by microfractures. Although clinopyroxenes locally have well-developed kink bands and deformation lamellae, the gabbro preserves the subophitic texture. An origin of frictional melts as a plastic instability (Hobbs and Ord, 1988) in a deforming shear zone seems to be incompatible with our observations. The textures found in the pseudotachylyte are typical of frictional melts formed during seismic faulting (Magloughlin, 1992). The change from euhedral crystals in the vein centre to dendrite at the vein rims suggests that the fassaitic pyroxene crystallized directly from the melt. Thus the dendritic texture supports the structural observations, which demonstrate that the veins are the result of faulting and represent true frictional melts. The spherulitic/dendritic textures shown in Figs 2(c) and 3(b-d) are similar to those produced during quenching of melt in experiments.

\section{Discussion}

The pseudotachylytes described occur in a blueschist facies terrain that experienced maximum metamorphic conditions of $550 \pm 50{ }^{\circ} \mathrm{C}$ and $15-$ $20 \mathrm{kbar}$, corresponding to subduction at a depth of $45 \mathrm{~km}$ or more. Although we cannot provide quantitative depth estimates for the faulting, the veins contain neoblasts and parageneses characteristic of blueschist facies metamorphism (glaucophane and other high-pressure amphiboles such as barroisite). The composition of the dendritic pyroxene with a high CaEs component is in accordance with pyroxene formed at $10 \mathrm{kbar}$ (Spray, 1988) and further supports the idea that the seismic faulting occurred at considerable depth. Occurrence of pseudotachylyte at HP-LT conditions in the eclogite facies has previously been documented 
from the orogenic root zone of the Caledonides in Western Norway (Austrheim and Boundy, 1994; Lund and Austrheim, 2003). These pseudotachylytes occur in dry Precambrian granulites and gabbros and it was argued that seismicity was an integral part of the fluid-driven Caledonian (420 Ma) eclogitization of the root zone by assisting fluid transport (Bjornerud et al., 2002). These observations have recently been taken to support models of a dry, strong and seismically active lower crust beneath the Himalayas (Jackson, 2002). The Alpine example reported here has several analogies with the Caledonian HP-LT pseudotachylytes. The complex is partly metamorphosed to HPLT assemblages and pseudotchylytes have been identified in rocks that partly preserve their previous mineralogy and textures. This suggests that dry strong rocks are a prerequisite for the faulting that produces pseudotachylyte. However, clasts of talc and inclusions of globular serpentine may give support for some hydration prior to faulting. A detailed search for dehydration textures on a regional scale is required to test whether the dehydration reaction represented by serpentine to olivine is related to a regional heating event and therefore supports existing models for subduction zone earthquakes (Hacker et al., 2003) or if the dehydration took place during shear heating as suggested here. Pseudotachylytes have recently also been described from the Shimanto accreationary complex in Japan by Ikesawa et al. (2003). The finding of palaeo-seismic fault zones in subduction complexes is exciting and represents a new source of information on subduction earthquakes. We anticipate that similar relationships will be found in other subduction complexes and blueshist terrains, which will open a new avenue for research towards a better understanding of subduction zone processes.

\section{Acknowledgements}

Professor Bradley R. Hacker and Dr Muriel Erambert are thanked for comments and improvements to an early version of the text. We thank Joseph Allen and Hideo Takagi for constructive reviews. We thank Laurent Jolivet for introducing us to the geology of Alpine Corsica. Financial support was received from PGP (H.A. and T.B.A.) and NGU (T.B.A.).

\section{References}

Austrheim, H. and Boundy, T.M., 1994. Pseudotachylytes generated during seismic faulting and eclogitization of deep crust. Science, 265, 82-83.

Bjornerud, M.G., Austrheim, H. and Lund, M.G., 2002. Processes leading to eclogitization (densification) of subducted and tectonically buried crust. J. Geophys. Res. 107, DOI 10.1029/2001JB000527.

Bucher, K. and Frey, M., 1994. Petrogenesis of Metamorphic Rocks. Springer Berlin.

Fournier, M., Jolivet, L., Goffe, B. and Dubois, R., 1991. Alpine Corsica Metamorphic core complex. Tectonics, 10, 1173-1186.

Hacker, B.R., Peacock, S.M., Abers, G.A. and Holloway, S., 2003. Subduction factory 2. Are intermediate-depth earthquakes in subduction slabs linked to metamorphic dehydration reactions? J. Geophys. Res., 108, DOI 10.1029/2001JB001129.

Hobbs, B.E. and Ord, A., 1988. Plastic instabilities: implications for the origin of intermediate and deep focus earthquakes. J. Geophys. Res., 93, 10521-10540.

Ikesawa, E., Sakaguchi, A. and Kimura, G., 2003. Pseudotachylyte from an ancient accretionary complex: evidence for melt generation during seismic slip along a master décollement? Geology, 31, 637-640.

Jackson, J., 2002. Strength of the continental lithosphere: time to abandon the jelly sandwich? GSA Today, 12, 4-10.
Jolivet, L., Faccenna, C., Goffe, B., Burov, E. and Agard, P., 2003. Subduction tectonics and exhumation of high-pressure metamorphic rocks in the Mediterranean orogens. Am. J. Sci., 303, 353-409.

Katayama, I., Parkinson, C.D., Okamoto, D., Nakajima, Y. and Maruyama, S., 2000. Supersililicic clinopyroxene and silica exolution in UHPM eclogite and pelitic gneiss from the Kokchetav massif, Kazakhstan. Am. Miner., 85, 1368-1374.

Kretz, R., 1983. Symbols for rock-forming minerals. Am. Miner., 68, 277-279.

Lahondre, D., 1988. Eclogitic metamorphism in Farinoles orthogneisses and ophiolitic metabasites (Northern Corsica, France). Bull. Soc. Geol. France, 4, 579-585.

Lund, M.G. and Austrheim, H., 2003. High-pressure metamorphism and deep-crustal seismicity: evidence from contemporaneous formation of pseudotachylytes and eclogite facies coronas. Tectonophysics, 372, 59-83.

Magloughlin, J.F., 1992. Microstructural and chemical changes associated with cataclasis and frictional melting at shallow crustal levels: the cataclasitepseudotachylyte connection. Tectonophysics, 204, 243-260.

Sibson, R.H., 1975. Generation of pseudotachylyte by ancient seismic faulting. Geophys. J. Astr. Soc., 43, 775-794.

Spray, J.G., 1988. Generation and crystallization of an amphibolite shear melt: an investigation using radial friction welding. Contrib. Miner. Petrol., 99, 464-475.

Warburton, J., 1986. The ophiolite-bearing Schistes lustrés nappe in the Alpine Corsica: a model for the emplacement of ophiolites that have suffered HP/LT metamorphism. Geol. Soc. Am. Mem., 164, 313-331.

Wenk, H.R. and Weiss, L.E., 1982. Al-rich calcic pyroxene in pseudotachylyte: an indicator of high pressure and high temperature? Tectonophysics, $\mathbf{8 4}$, 329-341.

Received 24 October 2003; revised version accepted 19 March 2004 